\title{
Effect of Socio-Economic Characteristics of Farmers on Their Adoption of Organic Farming Practices
}

\author{
O.M. Adesope1, E.C. Matthews-Njoku², N.S. Oguzor ${ }^{3}$ and V.C. Ugwuja ${ }^{1}$ \\ ${ }^{1}$ Department of Agricultural Economics and Extension \\ University of Port Harcourt \\ ${ }^{2}$ Department of Agricultural Extension \\ Federal University of Technology, Owerri \\ ${ }^{3}$ Federal College of Education (Technical), Omoku \\ Nigeria
}

\section{Introduction}

Organic farming is a form of agriculture which excludes the use of synthetic fertilizers, pesticides and plant growth regulators. The system also seeks to maintain the fertility demands of various crops to avoid excessive depletion of soil nutrients. Organic scientists and farmers in Africa, therefore deliberately integrates the age-long traditional organic system to enable a holistic development of the organic sector that would make use of the locally available resources, drawing from the pragmatic experiential knowledge of the farmers thereby making it highly relevant and acceptable to the majority of Africa. According to Parrot, Ssekyyew, Makunike, and Ntambi (2006), farmers have often resisted "Green revolution" viewing them not only as unsuitable but also risky and inaccessible. The concept of organic farming practices refers to the farm as an organism in which all the component parts (the soil minerals, plants, organic matter, micro-organisms, insects, animals including humans) interact to create a coherent and stable whole. Organic farming combines scientific knowledge of ecology and modern technology with traditional farming practices based on naturally occurring biological processes. Organic farming is based on ecological processes; knowledge of the agro-ecosystem is thus a pre-requisite to any organic farm. To this end, farmers with a traditional knowledge base are potentially better able to develop ecological processes. Traditional knowledge is not just a system for the present, but a source of institutional memory about what practices have worked best over time. Such knowledge has been described as a "reservoir of adaptations"; a whole set of practices that may be used again if the need arises (FAO, 2008).

Organic farming provides basis for maintaining environmental goods and services at the farm and landscape level. According to FAO, (2008), organic agriculture provides environmental goods and services. It promotes ecological resilience, improved biodiversity, healthy management of farms and the surrounding environment, and builds on community knowledge and strength. Hence, organic farming has been proved to be effective for enhanced adaptive capacity of farmers' socio-economic factors which necessitates social 
changes that are sometimes unacceptable to the local community. This might be successful in some communities but not in others; no doubt these factors include age, gender, farmers household size, educational status, farm size, level of personal income, membership of cooperatives, access to credit, number of extension contacts, policy problems and prospects, poverty, closeness to markets infrastructural facilities provided such as roads, electricity, housing, schools, clinics, potable water. Gender plays a role in organic farming practices, despite the fact that women participate more than men in agriculture in developing world, they remain more malnourished and less economically empowered because of the past, generally development assistance failed to reach women in rural areas.

Kang (2007) explains that today mainstreaming of gender of all levels in the agricultural sector is actively being done in order to address the issue of gender disparities. Mgbada (2000), Rahman and Usman (2004), and Ibrahim et al (2000), noted that rural women contribute two thirds of the labor force spent in agricultural production and marketing by producing up to $60-80 \%$ of food and other products in Nigeria and Africa at large. Adu, Famiyide, Adejoba, Ojo, Thomas, and Adebayo (2003), claimed that majority of rural women took active part in agricultural production, in addition to their domestic activities women should be encouraged when it comes to farming since they are responsible for small scale agriculture farm labor force and day-to-day family sustenance. This implies if women are well empowered in terms of organic farming practices, this will help to reduce scarcity of food and poverty level in the country. Poverty, does not only affect organic farming but the rural people in developing counties, and when the people are affected the production system is also affected. Ekong (2003), sees poverty as not only an expression of life condition, but a state of mind and preparation of self in the complex web of social relations. The high poverty level in Nigeria is ironic given the vast human materials and natural resources present in the country. Interestingly, this is why the country was placed among the poorest nations.

\section{Benefits of Organic Farming Practices}

Organic farming is beneficial in agriculture because it provides basis for healthy foods and healthy living. Organic agriculture reduces external inputs by controlling pests and diseases naturally, with both traditional and modern methods, increasing both agricultural yields and disease resistance. Organic farming practices enhance soil structures, conserve water and ensure sustained biodiversity. Through its holistic nature, organic farming integrates agro-biodiversity and soil conservation, and takes low intensity farming one step further by eliminating the use of chemical fertilizers, pesticides and genetically modified organism, which is not only an improvement for human health and agro biodiversity, but also for the associated off farm communities. According to Food and Agriculture Organization (FAO, 2008), organic agriculture promotes ecological resilience, improved biodiversity, healthy management, off-farms and the surrounding environment, and building on community knowledge and strength.

Despite the fact that much progress has been made, problems resulting from pests and diseases are still a major reason for lower yields but this problem could be addressed through plant breeding efforts under the special conditions of organic farming practices. Organic agriculture seeks to utilize those advances for consistent yield benefits (new varieties of crops, agricultural technologies, more efficient machinery) while discarding those methods that have impacted negatively on the society. Rod (1990), stated that sustainable agriculture systems rely more on crop rotation, crop residues, animal manures, 
legumes, green manures, off-farm organic waste, appropriate mechanized cultivation or minimal tillage to optimize soil biological control activities and thereby maintain soil fertility and crop fertility and crop productivity. According to Wikipedia (2007), organic farming technology relies on agronomic biological and mechanical method. This will help in environmental awareness and concern increase amongst the general population thereby enhancing inputs and sciences upon food because when technology and mechanical method has taken over it will take away some drudgery that which would have been a hindrance to increase in productivity.

Organic farming is beneficial when it comes to fauna and floral due to, in terms of its floral activities it helps to improve the soil fertility and this in turn increases the yield in crops while in fauna it is essential in the world of wildlife especially our livestock because most of our cattle's emits methane and we mostly produce them for its milk and meat, but with organic farming there is tendency for the grass which they feed on to grow all season of the year, this is to enable these livestock to still be in there physical health condition. Stolze (2000) reported that organic farming clearly performs better than conventional farming in respect to floral and fauna diversity, however it direct measure for wildlife and biotype conservation. Rigby and Caceres (2001), noted that in terms of soil, it is concluded that organic farming tends to conserve soil fertility and system stability. By conserving its soil fertility it will help the farmer to increase the humus content of the soil which will in turn improve the physical properties of the soil and support the life of micro-organism in the soil, which will help in increasing the pore spaces in the soil thereby improving drainage that aids to the stability of the soil structures and components.

\section{Adoption of Organic Farming Practices}

Rogers (1995), stated that the adoption of innovation is related to innovation decision process through which an individual passes from first knowledge of an innovation, to forming an attitudes towards the innovation, deciding to adopt or reject the innovation, implementing the new ideas, and confirming the innovation decision. This implies that organic farming can only be accepted by rural farmers when they have passed through the innovation to decision process and these farmers have picked interest concerning this because, when a farmer picks interest, he tends to seek for more information on his own and when this happens adoption can take place. Adoption models are generally based on the theory that farmers make decisions in order to maximize hand, farmers utility depends on optimizing the productivity and minimizing the cost of cultivation to attain maximum profits. Feder (1985), stated that farmers adopt or practice new technologies when they expect a more profitable outcome that is gained from the existing technology.

Optimizing this utility may also include considerations such as health benefits, environmental concerns, food security and risk (Napier, 2000). They further put explains that for an individual to go into adoption when it comes to organic farming he first wants to know if his health is at risk by finding out if the organic practice will be harmful to his crop and in turn becomes poisonous to human, and he will also consider that if he is using his farm for mixed cropping will organic farming practice enhance the growth of one plant and kill others or will the advantages be greater than the disadvantages before the farmers can finally adopt. The adoption of an innovation can be measured as the extent of its use, producing a continuous dependent variable, or simply the use of the innovation, with organic farming adoption defined as growing crops using organic method of cultivation. Adesina and Zinnah (2003) emphasized the impact of farmers perceptions on innovation 
related characteristics in measuring adoption. In this study organic farming practices, adoption was described as a mental process, farmers go through a stage or some stages of being aware or knowledgeable of organic farming related technology, to forming positive or negative perception towards organic farming and ultimately decide weather to adopt or not. This process can be influenced by a wide variety of factors, including household factors (socio-economic, resource base), community factors (access to extension, market, credit) and perception towards organic farming. Rogers (2003), reviews that diffusion theory provides a model for the diffusion-innovation process, which extension professionals as change agents can use as a media which will attract innovators and early adopters. According to Rogers (2003), the five important attributes of innovation related to an individual's attitude toward an innovation and whose stage in the innovation decision process summarized by Rogers are relative advantage, compatibility, complexity, observable and trial.

When all these attributes are put together with the guide of an extension agent it enhances or speeds up adoption and farmers will be willing to adopt despite the formal mindset the farmer had towards adoption. The perceived attributes of an innovation would vary according to individuals different personal characteristics (age, communication channels). Perception about these attributes of innovation will influence adoption behavior. Based on adoption, Rogers (2003), divided innovation adopters into five category; innovators, early adopters, early majority, late majority and laggards. Each category of adopters has different characteristics according to their socio-economic status, personality values, and communication behavior. This implies that how the extension service tends to communicate with the farmers because, when you communicate wrongly to the farmers there is the tendency of message misinterpretation and this will affect adoption. Rogers (2003), defined interpersonal delivery method as a face-to-face exchange between individuals. This explains that the extension services can speak to the farmer based on face-to-face contact were if the farmer has difficulty in any of the stages he can share with the extension agent and the correction will be made.

The main objective of the study was effect of socio-economic characteristics of farmers on their adoption of organic farming practices. Specifically, the study describes the sociodemographic characteristics of the respondents, determine the level of adoption of organic farming practices, determine the perceived benefits of using organic farming practices among respondents and determine the relationship between socio-economic characteristics of farmers and their adoption of organic farming practices.

\section{Methodology}

The study was carried out in Rivers State in Niger Delta, Nigeria. The sampling frame consisted of a list of farmers obtained from the Rivers State Agricultural Development Programme, the sole agency of Agricultural Extension activities in the State. A structured questionnaire was administered to 90 randomly selected farmers from the study area. Data analysis was by the use of frequency, mean, percentage, and Pearson correlation.

In order to measure the level of adoption (dependent variable), 14 items (organic farming practices) were presented to the respondents based on a 7-point scale of Not aware (NA) $=1$, Aware $(\mathrm{A})=2$, Interest $(\mathrm{I})=3$, Evaluation $(\mathrm{E})=4$, Trial $(\mathrm{T})=5$, Adoption $(\mathrm{A})=6$, Discontinuance $($ Discont $)=7$. The independent variables (socio-economic characteristics) were analyzed thus; Gender (Male $=1$, Female $=2$ ); Age of farmers (years); Highest educational qualification (No formal education=1, Adult education=2, Primary=3, 
Secondary $=4$, Tertiary $=5$ ). Household size (number of persons in a household); Extension visit (Yes =1, No = 2); Membership of cooperatives societies (Yes =1, No =2); Farming experience (years); Marital status (Single $=1$, Married $=2$ ); Sources of information (friends/relatives/neighbor $=1$, Extension agent $=2$, Radio=3, Television=4, Newspaper=5, others $=6$ )

\section{Results and discussion}

Table 1 shows that $34.4 \%$ of the farmers were male, while $65.6 \%$ were female. From the table it is obvious that majority of the respondents are females. Also, $14.4 \%$ of the farmers were between the ages of 31 and 40 years old, 36.7\% were between 41 and 50 years, $26.7 \%$ were between 51 and 60 years, while $22.2 \%$ were 61 years and above. The findings revealed that, a significant proportion of the farmers were between 41 and 50 years indicating that the farmers were mainly middle aged who are in their economically active stage and as such, can undergo the stress and this has implication for productivity of the farmers.

The result from the Table 1 shows that $26.7 \%$ of the farmers had no formal education, $33.3 \%$ had adult education, $22.2 \%$ of the farmers had primary education while $6.7 \%$ of the farmers attained primary education and $11.1 \%$ received tertiary education. The findings show that the a higher proportion of the respondents had adult education qualification $(33.3 \%)$. Findings show that a reasonable percentage (48.9\%) of the farmers had 6 to 10 members in their households. About $32.2 \%$ of the farmers were single, while $67.8 \%$ of the farmers were married. It was also found that $32.2 \%$ of the farmers were members of cooperative societies while $67.8 \%$ were not. Since majority were not members of cooperative societies, their access to farm resources like agro-inputs, credits and even extension contact might be lean and this would not encourage adoption.

Findings showed that $56.7 \%$ of the respondents had 6 to 10 years farming experience, $42.2 \%$ have been visited by extension agents, while $57.8 \%$ were not visited by extension agents. This is not too good because visit or contact with extension provides opportunity for transfer of skill, knowledge and information which facilitate adoption.

About $44.4 \%$ of the farmers know about organic farming practices through friends/relatives/ neighbors, $27.8 \%$ of the farmers know about the practice through extension visit, $7.8 \%$ of the farmers got to know about the practice through radio, $4.4 \%$ got the information through television, while $7.8 \%$ of the farmers got to know about organic farming through the newspaper.

Variables

Gender

Male

Female

Age (Years)

$31-40$

$41-50$

51-60

61 and above

Highest Educational Qualification

No formal education

Adult education

\section{Frequency}

31

59

13

33

24

20

24

30
Percentage

34.4

65.6

14.4

36.7

26.7

22.2

26.7

33.3 
Primary education

Secondary education

Tertiary

Household Size

1-5

6-10

11-15

33.3

16 and above

1.1

Marital Status

Single

32.2

Married

Membership of cooperative societies

Yes

No

Years in Organic Farming Practices

Extension visit

Yes

42.2

No

Sources of Information

Friends/Relations/Neighbours $\quad 40$

Extension Agents

Radio

Television

Newspaper

7.8

Others

Source: Field Survey, 2010.

Table 1. Socio-Economic characteristics of respondents $(n=90)$

\section{Adoption of organic farming practices}

The result in Table 2 indicated that about $68.9 \%$ of the farmers adopted the practice of crop rotation and mixed cropping as the major organic farming practices respectively, hoeing and hand weeding had $63.3 \%$, and slash and burn were $58.9 \%$ while intercropping recorded $50.0 \%$.

From the findings it is obvious that farmers adopted five (5) out of fourteen (14) listed organic farming practices, giving an adoption rate of $35.7 \%$. This indicates that level of adoption of organic farming practices is generally low; this could be as a result of the strenuous nature of some of the practices like hand picking of insects, tillage with sticks. The farmers are not very convinced about its merits, inability and poor disposition of farmers as well as the inability of extension visit to facilitate their adoption. 


\begin{tabular}{|c|c|c|c|c|c|c|c|}
\hline $\begin{array}{l}\text { ORGANIC FARMING } \\
\text { PRACTICES }\end{array}$ & NA & A & I & $\mathrm{E}$ & $\mathrm{T}$ & A & DISCONT. \\
\hline Crop Rotation & $2(2.2)$ & $14(15.6)$ & $6(6.7)$ & $3(3.3)$ & $3(3.3)$ & $62(68.9)$ & $0(0)$ \\
\hline Mixed Cropping & $0(0)$ & $13(14.4)$ & $4(4.4)$ & $2(2.2)$ & $6(6.7)$ & $62(68.9)$ & $3(3.3)$ \\
\hline Use of green manure & $1(1.1)$ & $14(15.6)$ & 14(15.6) & 14(15.6) & $29(32.2)$ & $18(20.0)$ & $0(0)$ \\
\hline Use of compost & $3(3.3)$ & $13(14.4)$ & $20(22.2)$ & $18(20.0)$ & $19(21.1)$ & $15(16.7)$ & $2(2.2)$ \\
\hline $\begin{array}{l}\text { Hand picking of } \\
\text { insects }\end{array}$ & $12(13.3)$ & $16(17.8)$ & $29(32.2$ & $19(21.1)$ & $8(8.9)$ & $3(3.3)$ & $3(3.3)$ \\
\hline $\begin{array}{l}\text { Use of leaves as } \\
\text { mulching materials }\end{array}$ & $14(15.5)$ & $18(20.0)$ & $18(20.0)$ & $10(11.1)$ & 10(11.1) & $19(21.1)$ & $1(1.1)$ \\
\hline $\begin{array}{l}\text { Hoeing/ weed } \\
\text { removal by hand }\end{array}$ & $4(4.4)$ & $15(16.7)$ & $5(5.6)$ & $4(4.4)$ & $4(4.4)$ & $57(63.3)$ & $1(1.1)$ \\
\hline Slash and burn & $9(10.0)$ & $13(14.4)$ & $4(4.4)$ & $0(0)$ & $9(10.0)$ & $53(58.9)$ & $2(2.2)$ \\
\hline Tillage with sticks & $11(12.2)$ & $29(32.2)$ & 13(14.4) & $5(5.6)$ & $13(14.4)$ & $8(8.9)$ & 11(12.2) \\
\hline $\begin{array}{l}\text { Use of air tight } \\
\text { containers for storage }\end{array}$ & $10(11.1)$ & $20(22.2)$ & $19(21.1)$ & 13(14.4) & $9(10.0)$ & $16(17.8)$ & $3(3.3)$ \\
\hline $\begin{array}{l}\text { Sun drying of farm } \\
\text { produce }\end{array}$ & $2(2.2)$ & $16(17.8)$ & $18(20.0)$ & 14(15.6) & $10(11.1)$ & $30(33.3)$ & $0(0)$ \\
\hline $\begin{array}{l}\text { Use of organic } \\
\text { manures }\end{array}$ & $3(3.3)$ & $21(23.3)$ & $18(20.0)$ & $8(8.9)$ & $19(21.1)$ & $21(23.3)$ & $0(0)$ \\
\hline Inter cropping & $6(6.7)$ & $20(22.2)$ & $4(4.4)$ & $4(4.4)$ & $9(10.0)$ & $45(50.0)$ & $2(2.2)$ \\
\hline Tree/hedges planting & $4(4.4)$ & $24(26.7)$ & 10(11.1) & $6(6.7)$ & $4(4.4)$ & $7(7.8)$ & $35(38.9)$ \\
\hline
\end{tabular}

NA; Not Aware, A; Awareness, I; interest, E; Evaluation, T; Trial, A; adoption, Discont; discontinuance

Figures in parenthesis are in percentages

Source: Field Survey, 2010.

Table 2. Level Of Adoption Of Organic Farming Practices

\section{Perceived benefits of using organic farming practices}

Fig. 1 shows that $41.1 \%$ of the respondents perceived that organic farming practices increased soil organic matter content, $22.2 \%$ perceived that they reduce input cost of farming, $26.7 \%$ perceived that they involved low risk in crop failure. Also, $81.1 \%$ indicated that it has a high social value of general acceptability. About $84 \%$ indicated that organic farming practices are compatible with their own cultural systems, $77.8 \%$ stated that they are inexpensive, $55.6 \%$ stated that organic farming practices are natural form of farming, while $22.2 \%$ indicated that they are environmentally friendly. 


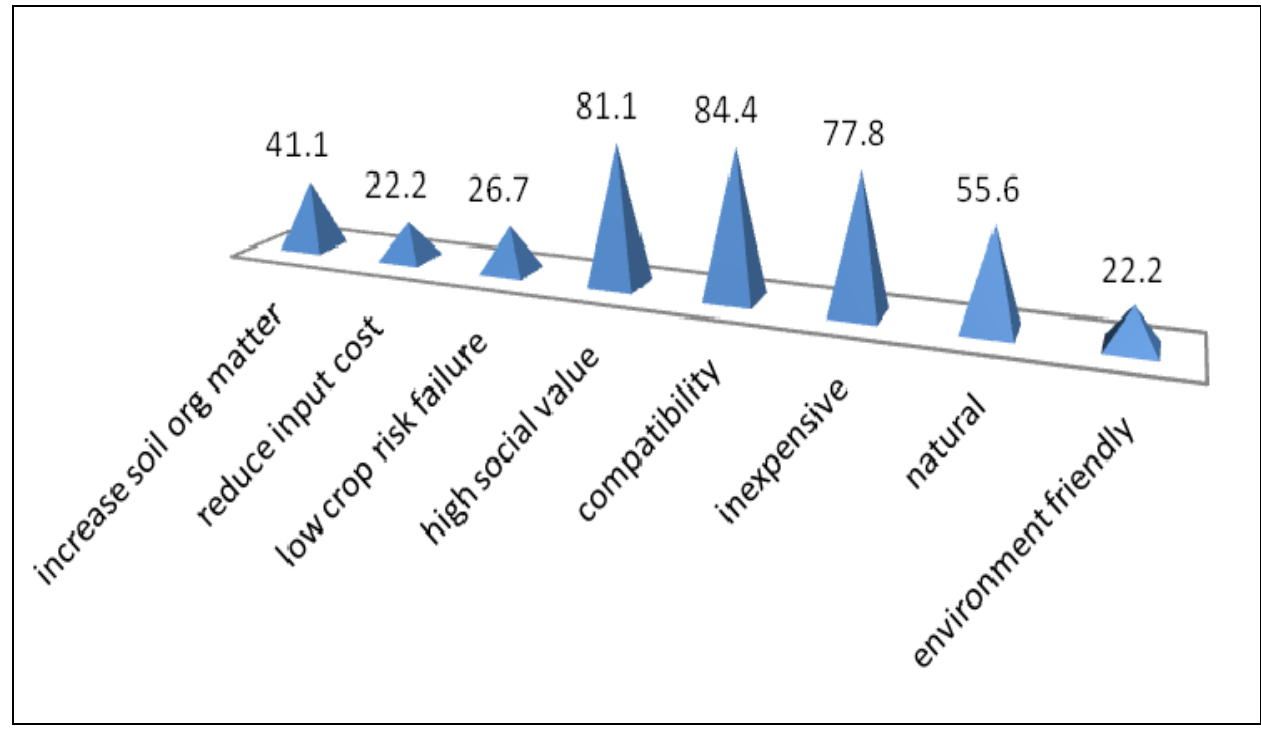

Fig. 1. Perceived benefitsof organic farming practices

\section{Relationship between socio-economic characteristics of farmers and adoption of organic farming practices}

Table 3 shows the results on relationship between socio economic characteristics of respondents and adoption of organic farming practices. From the findings only two variables correlated significantly with adoption of organic farming practices.

\begin{tabular}{lc}
\hline VARIABLES & r-VALUES \\
\hline SEX (GENDER) & 0.028 \\
AGE & -0.155 \\
EDUCATIONAL QUALIFICATION & 0.053 \\
HOUSEHOLD SIZE & 0.065 \\
MARITAL STATUS & $-0.221^{*}$ \\
MEMBERSHIP OF COOPERATIVES & 0.084 \\
FARMING EXPERIENCE & $-0.277^{* *}$ \\
EXTENSION VISIT & -0.001 \\
SOURCES OF INFORMATION & 0.020 \\
\hline
\end{tabular}

* = Significant at $0.05 \%$ level; ** = Significant at the 0.01 level

Table 3. Correlation coefficient of socio-economic characteristics of farmers and adoption of organic farming practices

Farming experience is negatively correlated with adoption of organic farming practices and significant at 0.01 level. This implies that there exist an inverse relationship between farmers experience and adoption which means that those with less farming experience have higher adoption level. This is in consonance with the findings by Edeoghon's (2008), who reported 
that farmers usually are more involved in practices that they are more familiar with than other practices. The findings also agree with the literature that organic producers are newer entrants to farming (Padel, 2001). This can be attributed to the fact that farmers who have been long in the business are usually older, less educated and more resistant to change than new entrants.

Marital status of farmers was found to be negatively correlated with adoption of organic farming practices which means there is an inverse relationship, but is significant at 0.05 level which means if both variables are cordial there would be increase in adoption. Marital status of respondents was an important factor in adoption of organic farming practices. This is in line with Ekong (2000), Nwachukwu and Jibowo (2000), Bamneke (2003), who reported that majority of respondents involved in agricultural activities are married.

\section{Conclusion}

The study concludes that adoption of organic farming practices was low as farmers adopted only 5 of the 14 practices identified. These include crop rotation, mixed cropping, hoeing and hand weeding, slash and burn and intercropping. It was found that respondents perceived that organic farming practices increased soil organic matter content, reduce input cost of farming, involved low risk in crop failure. Also, it was found that organic farming practices have high social value of general acceptability, are compatible with their own cultural systems, are inexpensive, are natural form of farming, and are environmentally friendly.

\section{Recommendations}

There is need to intensify efforts to make agricultural extension services more functional so that farmers can get useful information to enhance adoption of organic farming practices. Farmers should be encouraged for form and belong to cooperatives to facilitate group dynamism. Adequate enlightenment programmes should be mounted on organic farming practices so that more farmers can adopt.

\section{References}

Adesina A and Zinnah, M. (2003), 'Technology charateristics, farmer's perception and adoption decision: A Tobit model applicationin Sierra Leone'. Agricultural Economics , 9, 197-331.

Adesina A A, Mabila D, Nakamleu G B \& Endamana D 2000, ' Econometric analysis of the determinants of adoption of Alley Farming by farmers in the Forest Zone of southwest Cameroon.' Agric. Ecosys. Environ, 80, 255-265.

Adu, A. O., Famuyide, O.O, Adejoba, O.R., Ojo, M. O, Thomas, E.Y, and Adebayo, O. (2003): Gender uses in agro forestry development in three selected local government areas of Oyo state. A paper presented at the $9^{\text {th }}$ Annual conference of the forestry Association of Nigeria in Calabar Cross river state. $6^{\text {th }}-11^{\text {th }}$ October, 2003. 128-134.

Edeoghon, C.O ( 2008). Awareness and use of sustainable Agricultural practices by Arable crop farmers in Ikpoba Local government Area of Edo State. Journal of sustainable Development in Agricultural and Environment: Vol. 3No. 2, Ph 55-63 
Ekong E.W. (2000). Group and Non Group Women Farmers Access to Agricultural production, Responses in Akwa Ibom State, Nigeria. Ph.D. Thesis Department of Agricultural Ext and Rural Development, Ibadan: University of Ibadan.

FAO (2008). Organic Agriculture and climate change. Food and Agriculture Organization, Rome.

Feder, G., R.E.Just, and D. Zilberman (1985) "Adoption of Agricultural innovation in Developing Countries: A survey. Economic Development and cultural change, 33, 255-98

Kang Bhavdeep (2007). Women lead the way back to Organic Farming, IFOAM. www.ifoam.org/growing organic viewed 28th October, 2009

Mgbada, J. U., (2000): Production of stable food crops by Women in Enugu and Eboyi States: Lessons for enhancing poverty alleviation programme. In T.A. Olowu (ed) Agricultural Extension and poverty allevation in Nigeria. Proceedings of the $6^{\text {th }}$ Annual National conference of the Agricultural Extension society of Nigeria.

Napier T L, (2000), 'Adoption of conservation tillage production systems in three Midwest watersheds.' J. soil cons. 53: 123-134

Padel, S. (2001). Conservation to organic farming: a typical example of the diffusion of an innovation? Sociologia ruralis 41,40-61.

Parrott, N., Sockyew A., C., Makunike, C. and Ntambi, S.N. (2006). Organic farming in Africa. In: Helga, W. and M. Yussefi (eds). The world of organic farming agriculture: statistics and emerging trends. A joint Publication of International Federation of Organic Agricuture movement, Bonn, Germany and research Institute of organic agriculture (FiBl) Frick Switzerland.

Rahman, S.A and J.I Usman (2004): comparative Analysis of women participation in Agricultural production in Northern and southern Kaduna State. Mobilizing investors for sustainable Agricultural Research, Development and production in Nigeria. Proceedings of the $30^{\text {th }}$ Annual conference of the Agricultural society of Nigeria held at the College of Agriculture Lafia, Nassarawa State, October $17^{\text {th }}-21^{\text {st }}$ p 103-113.

Rigby, D. and Caceres, D. (2001). Organic farming and Sustainablility of agricultural systems. Agricultural systems, 68: 21-40. Elsevier Ltd.

Rod (1990), in Matthews-Njoku,E.C., Adesope, O.M, Nakwasi, R.N and Agumagu A.C.; Benefits of Organic farming practices in Owerri West Local Government Area of Imo, state Nigeria. Proceedings of the $5^{\text {th }}$ National conference of Organic Agriculture Project in Tertiary Institutions in Nigeria Federal University of technology, Owerri, Nigeria. November 15-19, 2009. p 318

Rogers E M 1995, 'Diffusion of Innovations (4th Edition)'. New York: The Free Press.

Rogers E.M. (2003). Diffusion of Innovations (5 $5^{\text {th }} \mathrm{ed}$.) New York: The free press

Sanusi, R. A., C. A. Badejo and B. O. Yusuf (2006) Measuring Household food insecurity in selected local government areas of Lagos and Ibadan, Nigeria. Pakistan journal of Nut.

Stolze, M. (2000) Environmental impacts of organic farming in Europe. Organic farming in Europe: Economics policy. Stuttgart-Hohenheim 2000. Department of Economics, University of Hohenheim, Germany.

Wikipedia (2007). Importance of organic farming in Texas city 


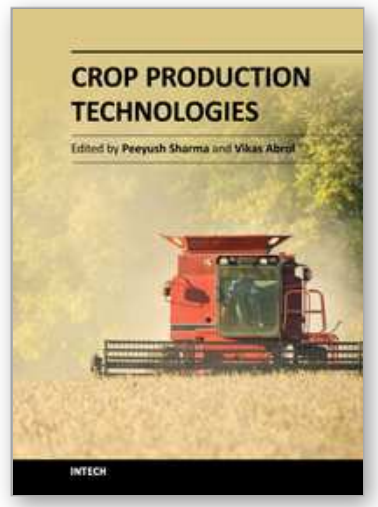

\author{
Crop Production Technologies \\ Edited by Dr. Peeyush Sharma
}

ISBN 978-953-307-787-1

Hard cover, 276 pages

Publisher InTech

Published online 05, January, 2012

Published in print edition January, 2012

Crop production depends on the successful implementation of the soil, water, and nutrient management technologies. Food production by the year 2020 needs to be increased by 50 percent more than the present levels to satisfy the needs of around 8 billion people. Much of the increase would have to come from intensification of agricultural production. Importance of wise usage of water, nutrient management, and tillage in the agricultural sector for sustaining agricultural growth and slowing down environmental degradation calls for urgent attention of researchers, planners, and policy makers. Crop models enable researchers to promptly speculate on the long-term consequences of changes in agricultural practices. In addition, cropping systems, under different conditions, are making it possible to identify the adaptations required to respond to changes. This book adopts an interdisciplinary approach and contributes to this new vision. Leading authors analyze topics related to crop production technologies. The efforts have been made to keep the language as simple as possible, keeping in mind the readers of different language origins. The emphasis has been on general descriptions and principles of each topic, technical details, original research work, and modeling aspects. However, the comprehensive journal references in each area should enable the reader to pursue further studies of special interest. The subject has been presented through fifteen chapters to clearly specify different topics for convenience of the readers.

\title{
How to reference
}

In order to correctly reference this scholarly work, feel free to copy and paste the following:

O.M. Adesope, E.C. Matthews-Njoku, N.S. Oguzor and V.C. Ugwuja (2012). Effect of Socio-Economic Characteristics of Farmers on Their Adoption of Organic Farming Practices, Crop Production Technologies, Dr. Peeyush Sharma (Ed.), ISBN: 978-953-307-787-1, InTech, Available from:

http://www.intechopen.com/books/crop-production-technologies/effect-of-socio-economic-characteristics-offarmers-on-their-adoption-of-organic-farming-practices

\section{INTECH}

open science | open minds

\section{InTech Europe}

University Campus STeP Ri

Slavka Krautzeka 83/A

51000 Rijeka, Croatia

Phone: +385 (51) 770447

\section{InTech China}

Unit 405, Office Block, Hotel Equatorial Shanghai

No.65, Yan An Road (West), Shanghai, 200040, China

中国上海市延安西路65号上海国际贵都大饭店办公楼 405 单元

Phone: +86-21-62489820 
Fax: +385 (51) 686166

Fax: +86-21-62489821

www.intechopen.com 
(C) 2012 The Author(s). Licensee IntechOpen. This is an open access article distributed under the terms of the Creative Commons Attribution 3.0 License, which permits unrestricted use, distribution, and reproduction in any medium, provided the original work is properly cited. 